\begin{tabular}{|c|c|}
\hline Вісник & Astronomi \\
\hline $\begin{array}{l}\text { Астрономічноі } \\
\text { школи }\end{array}$ & $\begin{array}{c}\text { School's } \\
\text { Report }\end{array}$ \\
\hline
\end{tabular}

ISSN 1607-2855

Tом 6 • № $2 \cdot 2009$ C. $141-150$

\title{
Physical parameters of gaseous and dust atmospheres of three comets 9P/Tempel 1, 37P/Forbes and C2004 Q1 (Machholz)
}

\author{
K.I. Churyumov ${ }^{1}$, V. Afanasiev ${ }^{2}$, E. Picazzio ${ }^{3}$, V.V. Kleshchonok ${ }^{1}$, I.V. Lukyanyk ${ }^{1}$, \\ V. Ponomarenko ${ }^{1}$, A. Baransky ${ }^{1}$, A. Almeida ${ }^{3}$, R.D.D. Costa ${ }^{3}$, L.S. Chubko ${ }^{4}$ \\ ${ }^{1}$ Kyiv Shevchenko National University, Ukraine \\ ${ }^{2}$ Special astrophysical observatory of RAS, Russia \\ ${ }^{3}$ Department of Astronomy, Institute of Astronomy, Geophysics and Atmospheric Sciences, University of S227, \\ San Paulo, Brazil \\ ${ }^{4}$ National Aviation University, Kyiv, Ukraine
}

\begin{abstract}
One of three explored comets 9P/Tempel 1 was the main target of space mission Deep Impact. We present the results of exploration of spectra of three comets 9P (Tempel 1), C2004 Q1 (Machholz) and 37P/Forbes observed in 2004-2005 at Observatorio do Pico dos Dias (Brazil) and at Mount Pastukhov and Peak Terskol (Russia). The detailed identification of emission lines in spectra of comet 37P/Forbes was made. BVRI photometry comets $9 P$ Tempel 1) and C2004 Q1 (Machholz) was carried out. Physical parameters of $C_{2}, C_{3}$ and CN gases in the near nucleus region of the cometary atmospheres of comets 9P (Tempel 1), C2004 Q1 (Machholz) and 37P/Forbes were determined. Presence of cometary luminescence continuum (non-solar origin) in the spectra of three comets are confirmed.
\end{abstract}

ФІЗИЧНІ ПАРАМЕТРИ ГАЗОВИХ ТА ПИЛОВИХ АТМОСФЕР ТРЬОХ КОМЕТ 9P/Tempel 1, 37P/FORВЕSI C2004 Q1 (MACHHOLZ), Чурюмов K., Афанас'єв В., Пікациіо Е., Клещенок В., Лук'яник I., Пономаренко В., Баранський О., Альмейда А., Коста Р., Чубко Л. - Одна з трьох досліджуваних комет 9P/Тетреl 1 був головною ціллю космічної місії Діп Імпект в 2005 р. Ми представляємо результати дослідження комет 9P/Tempel 1, 37P/Forbes i C2004 Q1 (Machholz), які cnостерігалися в 2004-2005 рр на обсерваторіях Пік Діас (Бразилія), на горі Пастухові (Росія) і піку Терскол (Росія). Проведено детальне ототожнення емісійних ліній в спектрі комети 37P/Форбса, BVRI фотометрію комет 9P /Tempel 1) i C2004 Q1 (Machholz). Розраховано фізичні параметри $C_{2}, C_{3} i C N$ газів в навколоядерних ділянках атмосфер комет 9P/Tетреl 1 , 37P/Forbes i C2004 Q1 (Machholz). Присутність кометного люмінесцентного континууму (не сонячного походження) в спектрах изих трьох комет підтверджується.

ФИЗИЧЕСКИЕ ПАРАМЕТРЫ ГАЗОВЫХ И ПЫЛЕВЫХ АТМОСФЕР ТРЕХ KOMЕТ 9P/Tempel 1, 37P/FORBES И C2004 Q1 (MACHHOLZ). Чурюмов К., Афанасьев В., Пикациио Э., Клещенок В., Лукьяник И., Пономаренко В., Баранский А., Альмейда А., Коста Р., Чубко Л. - Одна из трех исследуемых комет 9P/Tетреl 1 была главной иелью космической миссии Діп Импект в 2005 г. Мы представляем результать исследования комет 9P/Tempel 1, 37P/Forbes и C2004 Q1 (Machholz), которые наблюдались в 2004-2005 гг на обсерваториях Пик Диас (Бразилия), на горе Пастухова (Россия) и пике Терскол (Россия). Проведено детальное отождествление эмиссионных линий в спектре кометы 37P/Форбса, BVRI фотометрию комет 9P /Teтреl 1) u C2004 Q1 (Machholz). Рассчитаны физические параметры $C_{2}, C_{3}$ и CN газов в околоядерных участках атмосфер комет 9P/Tempel 1, 37P/Forbes и C2004 Q1 (Machholz). Присутствие кометного люминесиентного континуума (не солнечного происхождения) в спектрах этих трех комет подтверждается.

\section{INTRODUCTION}

High and middle-resolution optical comet spectra obtained with long slit allow to calculate some physical parameters of cometary neutral atmospheres (escaping velocities of gas in coma, life time of particles et other), search for new cometary emission lines, to estimate parameters of gas and dust productivity of comet nucleus, to detect the cometary luminescence continuum of the non-solar nature and other [3-10].

\section{OBSERVATIONS AND PROCESSING OF COMETARY SPECTRA}

The spectra of two well known short period comets 9P/Tempel 1 and 37P/Forbes observed at Observatório do Pico dos Dias (LNA - Laboratório Nacional de Astrofisica), Brasópolis (Brazil), in the course of 3-5 July, 2005. Observers are R.D.D.Costa and Andre Escudero. Helio- and geocentric distances of the comets $r$ and $\Delta$ and their magnitudes $m_{1}$ were on July 3-5, 2005: for comet 9P/Tempel $1: r=1.51 \mathrm{AU}$, $\Delta=0.89 \mathrm{AU}, m_{1}=9.9^{m}$ and for comet 37P/Forbes: $r=1.60 \mathrm{AU}, \Delta=0.68 \mathrm{AU}, m_{1}=12^{m}$.

Spectroscopic observations of comets 9P/Tempel 1 and 37P/Forbes were made on July 3-5, 2005 with the help of the Cassegrain spectrograph, using a 900/500 grating, attached to the Perkin \& Elmer 1.6-m ISSN 1607-2855. Вісник Астрономічної иколи, 2009, том 6, № 2 
Table 1. Observational data for comets 9P/Tempel 1 and C/2004 Q2 (Machholz)

\begin{tabular}{|c|c|c|c|c|c|}
\hline Date \& Time, UT & $r, \mathrm{AU}$ & $\Delta, \mathrm{AU}$ & Time of exposure, sec & Phase angle & Comet \\
\hline 2004-Dec-18 21:15 & 1.33 & 0.43 & 3600 & 30 & $\mathrm{C} / 2004 \mathrm{Q} 2$ \\
2005-Mar-15 21:56 & 1.85 & 0.91 & 600 & 14.6 & $9 \mathrm{P}$ \\
2005-Mar-15 20:56 & 1.43 & 0.92 & 600 & 43.7 & $\mathrm{C} / 2004 \mathrm{Q} 2$ \\
\hline
\end{tabular}

telescope of LNA. Spectral range: $\sim 374-526 \mathrm{~nm}$. Scales: $0.077355 \mathrm{~nm} /$ pix or $0.177 \mathrm{arcsec} / \mathrm{pix}$. The spectrograph slit was oriented to the East-West direction.

The short period comet 9P/Tempel 1 was observed with SCORPIO installed in the Prime Focus of the 6-m telescope of the Special Astrophysical Observatory of the RAS on March 14-16, 2005 (Mount Pastukhov, Nizhny Arkhyz, Northern Caucase, Russia) by L.S.Chubko, K.I.Churyumov and V.L.Afanasiev (fig.1). The observations were obtained 2.5 months before collision of the copper impactor of the Deep Impact spacecraft with the SCORPIO (Spectra Camera with Optical Reducer for Photometrical and Interferometrical Observations). During the same nights they observed also spectra of new comet C/2004 Q2 (Machholz) (Fig.2). Alltogether were obtained 4 spectra of comet C/2004 Q2 (Machholz) and two spectra of comet $9 \mathrm{P} /$ Tempel 1 . The focal reducer SCORPIO was used with long-slit (length of the slit is 2 arcmin, width of one is 1 arcsec).

Earlier 2 spectra of comet C/2004 Q2 (Machholz) were obtained during the night on 17-18 Dec. 2004 also with the help of the $6 \mathrm{~m}$ telescope of the Special Astrophysical Observatory of RAS and the MPFS spectrograph by L.S.Chubko, K.I.Churyumov, V.Panchuk and M.Yushkin. The Spectrograph is intended for 2D spectrophotometry of the extended objects with medium spectral resolution. Spectrograph is mounted in Prime Focus of the 6-m Telescope. Main optical parts of the spectrograph: enlarger lens, multi lens array, wide field spectrograph. Spectral range $3600-9600 \AA$, dispersion $0.75-3.0 \mathrm{~nm} / \mathrm{px}$. Observational data for comets C/2004 Q2 (Machholz) and 9P/Tempel 1 are given in Table 1.

\section{PROCESSING OF SPECTRA OF COMETS (TEMPEL 1), C2004 Q1 (MACHHOLZ) AND 37P/FORBES}

All CCD spectra of comets 9P (Tempel 1), C2004 Q1 (Machholz) and 37P/Forbes were processed with the help of the LONG-MIDAS and the Research System IDL computer programs allowing for reductions of the CCD bias level, cosmic ray particles, flatfielding, and night sky contribution (Figs. 1-3) The catalog of the spectral lines in comet De Vico-Swift [11] was used for identification of the emission lines in the spectra of comet 37P/Forbes. The result of identification of the emission lines in spectra of comet 37P/Forbes obtained on July 5, 2005 are given in the Table 2.

\section{IDENTIFICATION OF EMISSION LINES IN SPECTRA OF THE NEAR NUCLEUS REGIONS OF COMET 37P (FORBES)}

The following typical cometary lines were identified in the interval wave lengths $4446-4612 \AA$ : 35 of $\mathrm{C}_{2}, 12$ of $\mathrm{NH}_{2}$, unidentified lines were 33 .

\section{BVRI PHOTOMETRY OF COMETS 9P/TEMPEL 1, C/2004 Q2 (MACHHOLZ)}

Comets Tempel 1 and Machholz were observed with the SCORPIO spectrograph through BVRI filters and were obtained the following results:

As are seen from Table 3 color $B-V=0.7$ for comet $9 \mathrm{P}$ and $B-V=0.1$ for comet Machholz. BVRI photometry of comet Tempel 1 and Machholz had shown that comet 9P has color as the Sun (a little redder than the Sun), but comet Machholz was bluer very much than the Sun.

\section{PHYSICAL PARAMETERS OF COMETS 9P/TEMPEL 1, C/2004 Q2 (MACHHOLZ), 37P/FORBES}

In order to determine some physical parameters of gaseous components of the neutral cometary atmosphere (the gas component expansion $u$ and the lifetime of the particles $\tau$ ) we built a photometric profiles for the $\mathrm{C}_{2}, \mathrm{C}_{3}$ and $\mathrm{CN}$ emission lines along slit for selected comets (Figs. 5-7) Then the obtained monochromatic profiles were processed by Shul'man's model. Within this model the surface brightness was determined by the following formulas

$$
\lg \frac{I(\rho, \varphi+\pi)}{I(\rho, \varphi)}=1.72 \frac{\rho}{r_{0 C}} \sin \Theta_{0} \cos \varphi, \quad \frac{1}{2} \lg \frac{I(\rho, \varphi+\pi)}{I(\rho, \varphi)}=\mathrm{const}+\lg \left[\frac{r_{0 k}}{\rho} \int_{\rho / r_{0 k}}^{\infty} K_{0}(y) d y\right],
$$

where $I(\rho, \varphi+\pi)$ and $I(\rho, \varphi)$ are brightness surface of emission line along slit, $\rho, \varphi-$ polar coordinates on the picture plane with the polar axe directed to the Sun, $r_{0 C}=2 u^{2} / g$ - characteristic scale of the spheric 142 Churyumov K.I., Afanasiev V., Picazzio E., et.al. 
Table 2. Emissions lines in comet 37P/Forbes on July 4, 2005

\begin{tabular}{|c|c|c|c|}
\hline 4446.50 & 9.55000019 & - & Unid \\
\hline 4449.89 & 8.10999966 & - & Unid \\
\hline 4451.92 & 8.48999977 & - & Unid \\
\hline 4453.95 & 4.48000002 & 4453.51 & Unid \\
\hline 4456.66 & 7.50000000 & 4456.17 & Unid \\
\hline 4458.02 & 5.44000006 & 4458.02 & Unid \\
\hline 4460.05 & 7.42000008 & 4460.05 & Unid \\
\hline 4462.08 & 4.51000023 & 4462.08 & Unid \\
\hline 4465.46 & 6.67999983 & 4465.24 & Unid \\
\hline 4468.17 & 5.48000002 & 4468.09 & Unid \\
\hline 4470.20 & 3.84999990 & 4470.20 & Unid \\
\hline 4473.59 & 8.55000019 & 4473.77 & Unid \\
\hline 4476.97 & 7.44000006 & 4476.85 & Unid \\
\hline 4479.01 & 3.74000001 & 4478.93 & Unid \\
\hline 4480.36 & 7.40000010 & 4480.36 & Unid \\
\hline 4481.71 & 7.53999996 & 4481.10 & Unid \\
\hline 4483.74 & 8.56999969 & 4484.66 & Unid \\
\hline 4485.10 & 8.26000023 & 4485.29 & Unid \\
\hline 4487.81 & 8.64999962 & 4487.93 & Unid \\
\hline 4489.84 & 6.61999989 & 4489.90 & Unid \\
\hline 4492.54 & 10.31000042 & 4492.46 & Unid \\
\hline 4495.25 & 6.44999981 & 4494.96 & Unid \\
\hline 4497.96 & 7.42999983 & 4498.04 & Unid \\
\hline 4499.99 & 8.40999985 & 4500.16 & Unid \\
\hline 4502.02 & 9.43000031 & 4502.65 & $\mathrm{NH}_{2} \mathrm{~A}-\mathrm{X}(0,7,0)-(0,0,0) 303-211$ \\
\hline 4503.37 & 9.34000015 & 4503.09 & Unid \\
\hline 4506.76 & 10.31000042 & 4507.03 & Unid \\
\hline 4509.46 & 8.60000038 & 4509.68 & Unid \\
\hline 4510.82 & 10.46000004 & 4510.84 & $\mathrm{NH}_{2}$ A-X $(0,7,0)-(0,0,0) 101-111$ \\
\hline 4513.52 & 6.59999990 & 4513.52 & Unid \\
\hline 4515.55 & 7.63999987 & 4515.59 & $\mathrm{C}_{2}$ Swan 1-0 R1(87) R2(86) R3(85) \\
\hline 4518.26 & 10.35000038 & 4518.14 & Unid \\
\hline 4519.61 & 9.44999981 & 4519.69 & $\mathrm{C}_{2}$ Swan 1-0 R1(86) R2(85) R3(84) \\
\hline 4520.97 & 11.46000004 & 4521.42 & $\mathrm{NH}_{2} \mathrm{~A}-\mathrm{X}(0,7,0)-(0,0,0) 101-211$ \\
\hline 4522.99 & 8.47999954 & 4523.18 & $\mathrm{C}_{2}$ Swan 1-0 R1(85) R2(84) R3(83) \\
\hline 4524.35 & 6.23999977 & 4524.35 & Unid \\
\hline 4525.70 & 7.25000000 & 4525.55 & $\mathrm{NH}_{2} \mathrm{~A}-\mathrm{X}(0,6,0)-(0,0,0) 625-515$ \\
\hline 4527.05 & 7.67999983 & 4527.24 & $\mathrm{C}_{2}$ Swan 1-0 R1(84) R2(83) R3(82) \\
\hline 4528.41 & 7.71999979 & 4528.25 & $\mathrm{NH}_{2} \mathrm{~A}-\mathrm{X}(0,7,0)-(0,0,0) 202-312$ \\
\hline 4529.76 & 7.36999989 & 4529.86 & Unid \\
\hline 4531.11 & 6.36999989 & 4530.63 & $\mathrm{C}_{2}$ Swan 1-0 R1(83) R2(82) R3(81) \\
\hline 4533.82 & 9.57999992 & 4533.57 & $\mathrm{C}_{2}$ Swan 2-1 R1(79) R2(78) R3(77) \\
\hline 4535.85 & 8.36999989 & 4535.32 & $\mathrm{NH}_{2}$ A-X $(0,6,0)-(0,0,0) 423-313 \mathrm{bl}$ \\
\hline 4535.85 & 8.36999989 & 4535.32 & $\mathrm{NH}_{2}$ A-X $(0,7,0)-(0,0,0) 303-413 \mathrm{bl}$ \\
\hline 4537.87 & 11.27000046 & 4537.88 & $\mathrm{NH}_{2}$ A-X $(0,6,0)-(0,0,0) 523-413$ \\
\hline 4541.26 & 7.88000011 & 4540.82 & $\mathrm{NH}_{2} \mathrm{~A}-\mathrm{X}(0,6,0)-(0,0,0) 321-211$ \\
\hline 4543.96 & 7.15000010 & 4543.87 & $\mathrm{C}_{2}$ Swan 2-1 R1(76) R2(75) R3(74) \\
\hline 4545.99 & 8.57999992 & 4545.86 & $\mathrm{C}_{2}$ Swan 3-2 R1(73) R2(72) R3(71) \\
\hline 4548.69 & 8.36999989 & 4548.81 & $\mathrm{C}_{2}$ Swan 3-2 R1(72) R2(71) R3(70) \\
\hline 4551.40 & 10.39999962 & 4551.72 & $\mathrm{C}_{2}$ Swan 3-2 R1(71) R2(70) R3(69) \\
\hline 4552.75 & 9.14999962 & 4552.62 & $\mathrm{C}_{2}$ Swan 1-0 R1(77) R2(76) R3(75) \\
\hline 4554.78 & 6.71999979 & 4554.88 & $\mathrm{NH}_{2} \mathrm{~A}-\mathrm{X}(0,6,0)-(0,0,0) 221-211$ \\
\hline 4556.13 & 7.78000021 & 4556.51 & $\mathrm{C}_{2}$ Swan 1-0 R1(76) R2(75) R3(74) \\
\hline 4557.48 & 12.30000019 & 4557.56 & $\mathrm{C}_{2}$ Swan 3-2 R1(69) R2(68) R3(67) \\
\hline 4560.19 & 11.60000038 & 4560.42 & $\mathrm{C}_{2}$ Swan 3-2 R1(68) R2(67) R3(66) \\
\hline 4562.89 & 10.61999989 & 4563.33 & $\mathrm{C}_{2}$ Swan 3-2 R1(67) R2(66) R3(65) \\
\hline 4564.24 & 11.84000015 & 4564.41 & Unid \\
\hline 4566.94 & 14.56000042 & 4566.92 & $\mathrm{C}_{2}$ Swan 1-0 R3(71) \\
\hline 4570.32 & 7.36999989 & 4570.60 & $\mathrm{C}_{2}$ Swan 1-0 R1(72) R2(71) \\
\hline 4571.68 & 11.27000046 & 4571.79 & $\mathrm{C}_{2}$ Swan 3-2 R1(64) R2(63) R3(62) \\
\hline 4573.70 & 9.59000015 & 4573.79 & $\mathrm{C}_{2}$ Swan 1-0 R1(71) R2(70) \\
\hline
\end{tabular}




\begin{tabular}{|r|r|r|l|}
4575.05 & 10.27999973 & 4574.60 & $\mathrm{C}_{2}$ Swan 3-2 R1(63) R2(62) R3(61) \\
4576.41 & 10.48999977 & 4576.00 & $\mathrm{C}_{2}$ Swan 2-1 R3(64) \\
4579.11 & 10.64000034 & 4578.96 & $\mathrm{C}_{2}$ Swan 2-1 R3(63) \\
4581.81 & 8.14999962 & 4582.05 & $\mathrm{C}_{2}$ Swan 2-1 R1(64) R2(63) \\
4583.16 & 8.94999981 & 4582.80 & $\mathrm{C}_{2}$ Swan 3-2 R1(60) R2(59) R3(58) \\
4584.51 & 9.32999992 & 4584.35 & $\mathrm{C}_{2}$ Swan 1-0 R3(66) \\
4588.57 & 9.23999977 & 4588.52 & $\mathrm{NH}_{2}$ A-X (0,6,0)-(0,0,0) 221-331 \\
4591.27 & 9.30000019 & 4591.04 & $\mathrm{C}_{2}$ Swan 1-0 R3(64) \\
4592.62 & 8.72000027 & 4592.61 & $\mathrm{NH}_{2}$ A-X (0,6,0)-(0,0,0) 321-431 \\
4593.97 & 11.15999985 & 4593.98 & $\mathrm{C}_{2}$ Swan 1-0 R1(65) R2(64) \\
4595.99 & 11.36999989 & 4596.03 & $\mathrm{C}_{2}$ Swan 3-2 R1(55) R2(54) \\
4597.35 & 11.47999954 & 4597.53 & $\mathrm{C}_{2}$ Swan 1-0 R1(64) R2(63) \\
4599.37 & 9.64000034 & 4599.85 & $\mathrm{C}_{2}$ Swan 2-1 R1(58) R2(57) \\
4602.07 & 10.05000019 & 4602.59 & $\mathrm{C}_{2}$ Swan 2-1 R1(57) R2(56) \\
4604.10 & 7.57999992 & 4604.01 & $\mathrm{C}_{2}$ Swan 1-0 R3(60) \\
4605.45 & 8.53999996 & 4605.58 & $\mathrm{C}_{2}$ Swan 2-1 P1(93)R1(56)P2(92)R2(55)P3(91) \\
4606.80 & 9.43999958 & 4606.81 & $\mathrm{C}_{2}$ Swan 1-0 R1(61) R2(60) \\
4608.82 & 12.10000038 & 4608.83 & $\mathrm{C}_{2}$ Swan 3-2 R3(48) \\
4612.20 & 11.19999981 & 4612.24 & Unid \\
\hline
\end{tabular}

symmetry region, $u$ - expansion velocity, $g$ - acceleration of molecules in the gravity field of the Sun, $\varphi-$ an angle between the $z$ axis and $g$-vector, $r_{0 k}=2 u^{2} / g-$ characteristic size of a coma, $K_{0}(y)-M a c k$ Donald's function.

The physical parameters of neutral gaseous molecules $\mathrm{C}_{2}(5165 \AA), \mathrm{C}_{3}(4050 \AA), \mathrm{CN}(4200 \AA)$ velocity of expansion, lifetime, the legth pathes of parent and daughter molecules are given in the Table 4,5.

From Table 5 we see that real velocities of expansion of the $\mathrm{C}_{2}, \mathrm{C}_{3}$ and $\mathrm{CN}$ molecules in the coma of comet C/2000 WM1 diverse noticeably from velocity of expansion for gas, determined by Delsemme's formula $V=0.58 / \sqrt{r}$ which gives the values of expansion velocities.

Table 3. BVRI magnitudes of comets 9P/Tempel 1 and C/2004 Q2 (Machholz)

\begin{tabular}{|l|c|c|c|c|c|}
\hline Comet & Date & $\mathrm{B}$ & $\mathrm{V}$ & $\mathrm{R}$ & $\mathrm{I}$ \\
\hline 9P/Tempel 1 & $03 / 15 / 05$ & 16.5 & 15.8 & 15.5 & 15.3 \\
C/2004 Q2 & $03 / 14 / 05$ & 12.1 & 12 & 11.9 & - \\
\hline
\end{tabular}

Table 4. Physical parameters of neutral gaseous cometary components of $\mathrm{C}_{2}, \mathrm{C}_{3}$ and $\mathrm{CN}$ (Shulman's model)

\begin{tabular}{|l|c|c|l|c|}
\hline Species & Velocity, m/sec & Life time, $10^{6} \mathrm{~s}$ & Comet & Date \\
\hline $\mathrm{C}_{2}(5165 \AA)$ & 222 & 1.36 & $9 \mathrm{P} /$ Tempel 1 & $14 / 03 / 2005$ \\
$\mathrm{C}_{3}(4050 \AA)$ & 102 & 0.38 & $9 \mathrm{P} /$ Tempel 1 & $14 / 03 / 2005$ \\
$\mathrm{CN}(4200 \AA)$ & 67 & 1.35 & $9 \mathrm{P} /$ Tempel 1 & $14 / 03 / 2005$ \\
$\mathrm{CN}(4200 \AA)$ & $>300$ & $>50$ & Machholz C/2004 Q2 & $18 / 12 / 2004$ \\
$\mathrm{C}_{3}(4050 \AA)$ & 363 & 5.13 & Machholz C/2004 Q2 & $18 / 12 / 2004$ \\
$\mathrm{C}_{2}(5165 \AA)$ & 535 & 39.9 & Machholz C/2004 Q2 & $18 / 12 / 2004$ \\
$\mathrm{C}_{2}(5165 \AA)$ & 855 & 73.4 & Machholz C/2004 Q2 & $15 / 03 / 2005$ \\
$\mathrm{C}_{2}(5165 \AA)$ & 88 & 609 & $17 \mathrm{P} /$ Holmes & $02 / 11 / 2007$ \\
$\mathrm{C}_{2}(5165 \AA)$ & 209 & 25.6 & $37 \mathrm{P} /$ Forbes & $04 / 07 / 2005$ \\
\hline
\end{tabular}

Table 5. Physical parameters of neutral gaseous cometary components of $C_{2}, C_{3}$ and $C N$ (Hasers's model). Note: $L_{\mathrm{par}}(\mathrm{clc})$ - the calculated path length of a parent molecule, $L_{\mathrm{dau}}(\mathrm{clc})$ - the calculated path length of a daughter molecule

\begin{tabular}{|l|c|c|l|c|}
\hline Species & $L_{\text {par }}(\mathrm{clc})$ & Ldau $(\mathrm{clc})$ & Comet & Date \\
\hline $\mathrm{C}_{2}(5165 \AA)$ & $1.24 \cdot 10^{3}$ & $1.21 \cdot 10^{4}$ & $9 \mathrm{P} /$ Tempel 1 & $14 / 03 / 2005$ \\
$\mathrm{C}_{3}(4050 \AA)$ & - & - & $9 \mathrm{P} /$ Tempel 1 & $14 / 03 / 2005$ \\
$\mathrm{CN}(4200 \AA)$ & - & - & $9 \mathrm{P} /$ Tempel 1 & $14 / 03 / 2005$ \\
$\mathrm{CN}(4200 \AA)$ & $1.12 \cdot 10^{5}$ & $2.10 \cdot 10^{5}$ & Machholz C/2004 Q2 & $18 / 12 / 2004$ \\
$\mathrm{C}_{3}(4050 \AA)$ & $2.78 \cdot 10^{3}$ & $6.15 \cdot 10^{5}$ & Machholz C/2004 Q2 & $18 / 12 / 2004$ \\
$\mathrm{C}_{2}(5165 \AA)$ & $2.13 \cdot 10^{4}$ & $1.60 \cdot 10^{5}$ & Machholz C/2004 Q2 & $18 / 12 / 2004$ \\
$\mathrm{C}_{2}(5165 \AA)$ & $2.64 \cdot 10^{4}$ & $8.60 \cdot 10^{5}$ & Machholz C/2004 Q2 & $15 / 03 / 2005$ \\
$\mathrm{C}_{2}(5165 \AA)$ & $2.3 \cdot 10^{3}$ & $3.08 \cdot 10^{5}$ & $37 \mathrm{P} /$ Forbes & $04 / 07 / 2005$ \\
\hline
\end{tabular}




\section{SEARCH OF LUMINESCENCE CONTINUUM IN SPECTRA OF COMETS 9P/TEMPEL 1, C/2004 Q2 (MACHHOLZ), 37P/FORBES AND 17P/HOLMES}

The comet 9P/Tempel 1 - the main target of the Deep Impact mission was observed with SCORPIO 1 installed in the Prime Focus of the 6-m telescope of the SAO of the RAS on March 16-17, 2005 (Mount Pastukhov, Nizhny Arkhyz, Northern Caucase, Russia). The observations were obtained 2.5 months before collision of the copper impactor of the Deep Impact spacecraft with the 6-m nucleus of short periodic comet 9P/Tempel 1. During the same nights we observed also spectra of new comet C/2004 Q2 (Machholz).

We suppose that in spectra of comets 9P/Tempel 1 and Machholz (C/2004 Q2) we detected the real luminescent cometary continuum tied with the luminescence of the comet organic species which are in comet dust particles (CHON-particles).

\section{SEARCH AND DETECTION OF COMETARY LUMINESCENCE CONTINUUM IN SPECTRA OF COMETS C/2004 Q2 (MACHHOLZ), 9P/TEMPEL 1 AND 37P/FORBES}

For the first time a luminescence continuum was detected in the comet Halley (1P) spectrum by G.Nazarchuk, who found out two broad features with the maximum of intensity near 395 and $510 \mathrm{~nm}$ $[1,2]$. They were part of the scattered solar continuum. In this paper is investigated spectra of comets 9P/Tempel 1 and Machholz (C/2004 Q2), with the aim to determine the real level of the non-solar-origin

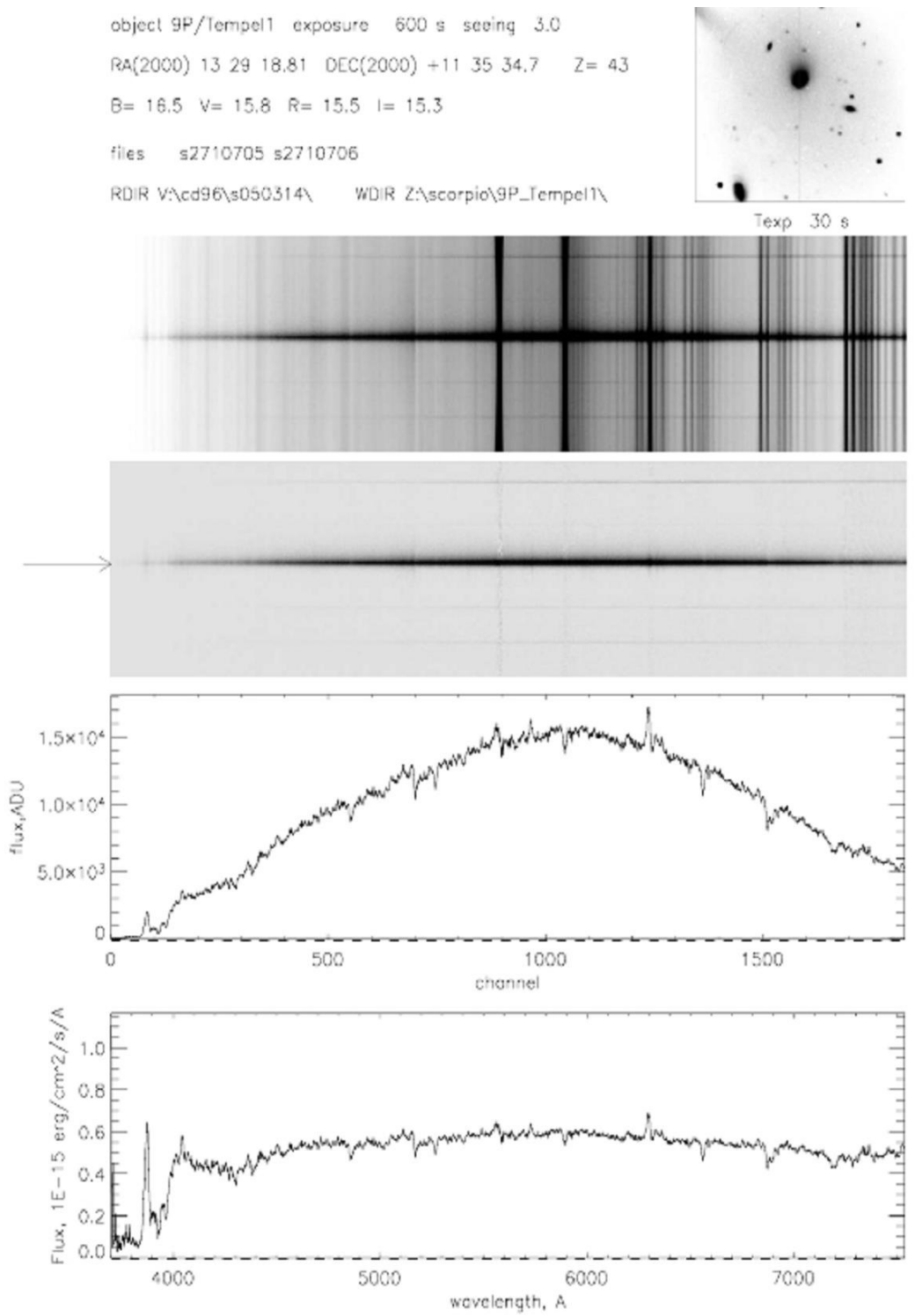

Fig. 1. The monochromatic image, the two slit spectra and distribution of energy in the spectrum of comet 9P/Tempel 1 on March 14, 2005 
continuum in the spectral region 350-600 nm. Spectra of these comets were observed with the help of the 6-m BTA telescope and the spectrograph SCORPIO with the long slit at the Special Astrophysical Observatory of the Russian Academy of Sciences. In the high spatial and spectral resolution spectra of several comets has been noticed, that the equivalent width of the basic Fraunhopher lines is less than in the solar spectrum (Fig. 1-2).

Such phenomenon is connected with presence of an additional component of a continuous spectrum in cometary radiation. As a source of this additional radiation the luminescence organic cometary motes can serve. That fact testifies that spatial distribution of this source finds out very strong concentration to a cometary nucleus.

Unfortunately, the luminescent luminescence in this case has a wide spectrum without significant features that complicates identification of a radiating material. Thus, a cometary spectrum Icom consists

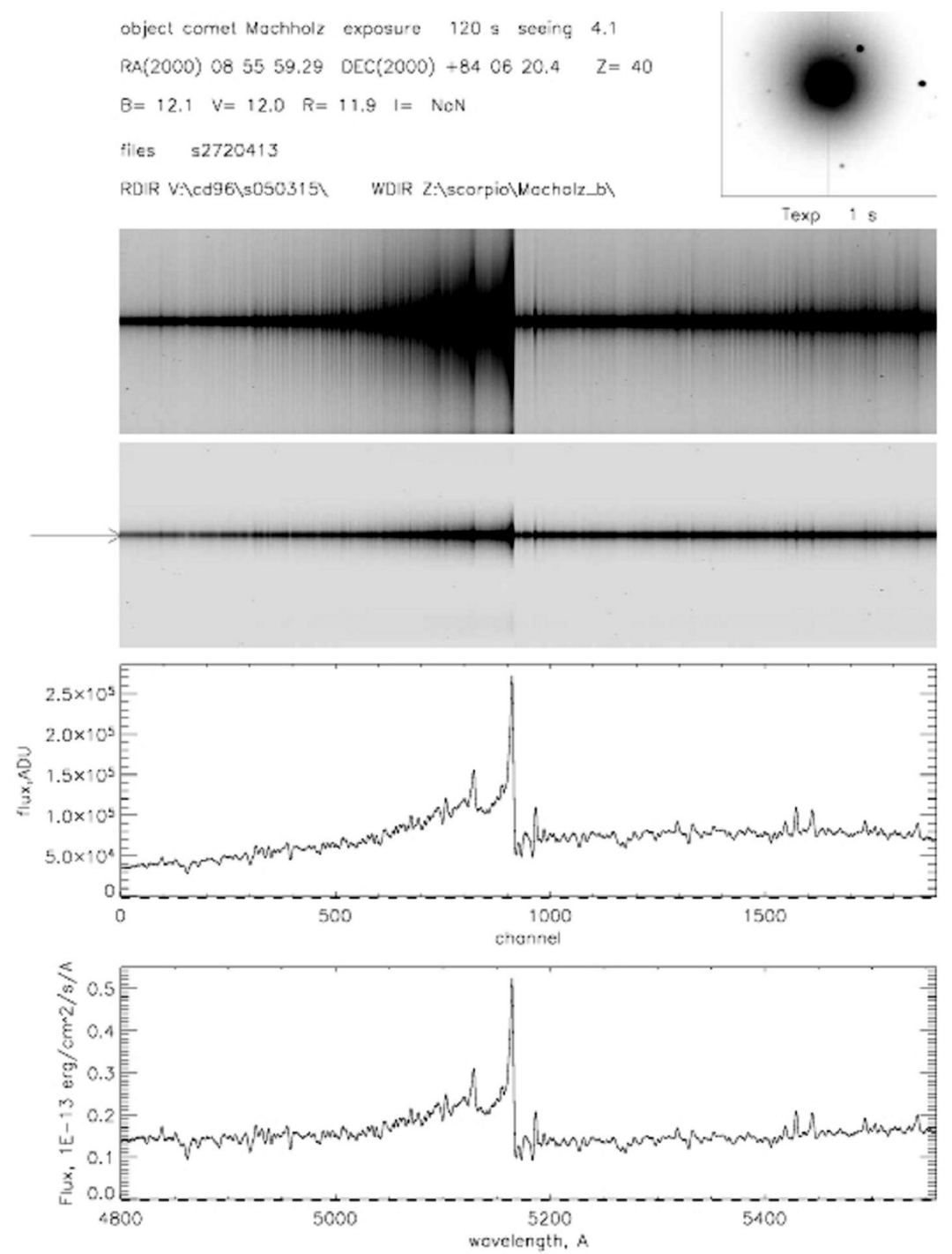

Fig. 2. The monochromatic image, the two slit spectra and distribution of energy in the spectrum of comet C/2004 Q2 (Machholz) on March 15, 2005

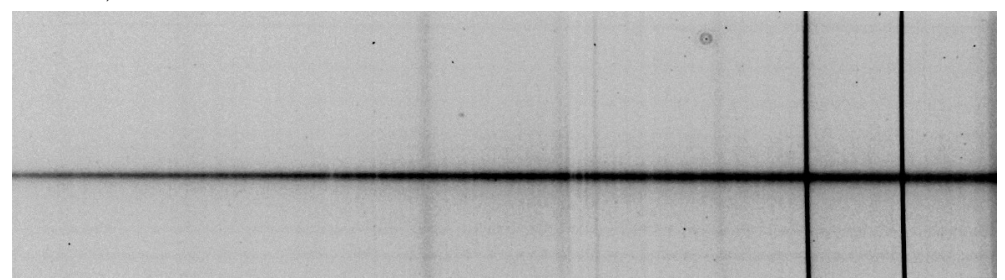

Fig. 3. The slit spectrum of comet 37P (Forbes) on July 4, 2005 
of three components:

$$
I_{\text {com }}(\lambda)=I_{e}(\lambda)+I_{s}(\lambda)+I_{l}(\lambda)
$$

where $I_{e}$ - an emission cometary spectrum, $I_{s}$ - the solar spectrum reflected by cometary dust, $I_{l}-$ a cometary luminescent continuum.

Spectral regions with no strong emission lines are selected for determination of a level of a luminescent continuum $I_{l}=0$. On these regions of a spectrum is accepted, that the level of a luminescent continuum does not vary. Thus, for the selected regions of a cometary spectrum it is possible to accept

$$
I_{\text {com }}(\lambda)=k \times I_{f}(\lambda)+l,
$$

where $I_{\text {com }}(\lambda)$ - the known solar spectrum which is calculated taking into account the spectral resolution of a cometary spectrum and its discontinuity, $k$ - factor which characterizes reflective ability of cometary dust, $l$ - intensity of a luminescent continuum. In practice parameters $k$ and $l$ are selected so that to receive the best accordance to a region of cometary continuum (fig. 8).

Uniting data on a level of a luminescent continuum for different spectral regions, gives possibility to study behaviour of a luminescent continuum in all cometary spectrum.

The given technique was used for studying a luminescent continuum in spectra of comets C/2004 Q2 Machholz and 9P/Tempel 1 (fig. 9-11).

The maximum of a luminescent continuum of comet C/2004 Q2 Machholz is close to 630 nanometers.
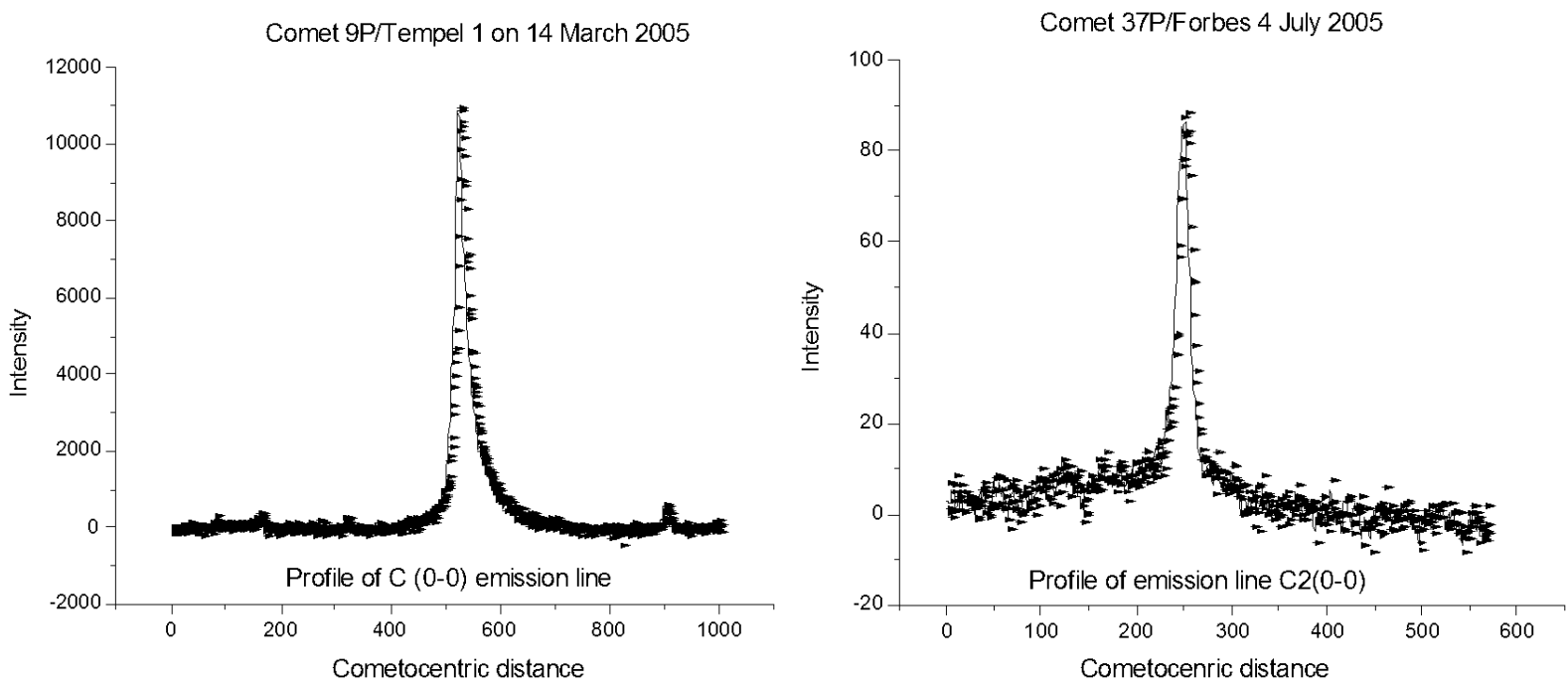

Fig. 4. Profile of brightness in the emission line $\mathrm{C}_{2}(0-0)$ in the spectrum of comet 9P (Tempel 1) on 14 March 2005

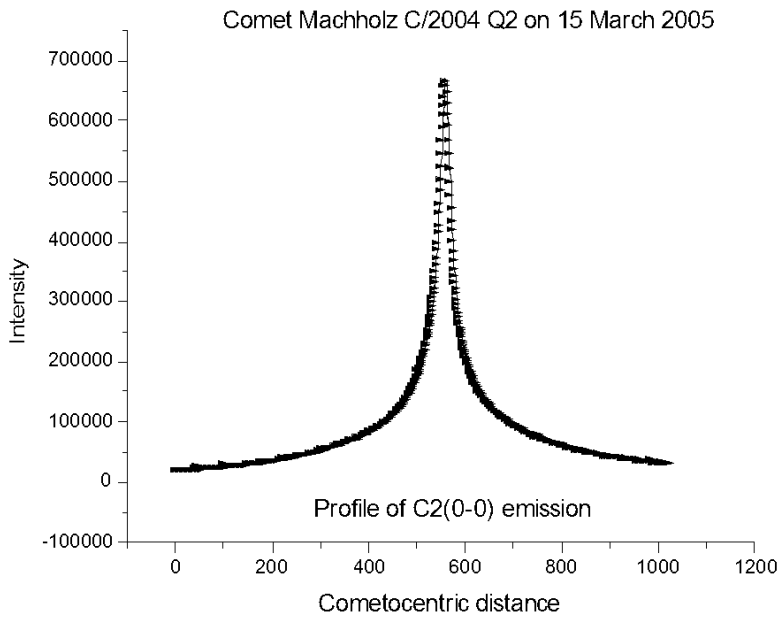

Fig. 6. Profile of brightness in the emission line $\mathrm{C}_{2}(0-0)$ in the spectrum of comet C/2004 Q2 (Machholz) on 15 Mar. 2005
Fig. 5. Profile of brightness in the emission line $\mathrm{C}_{2}(0-0)$ in the spectrum of comet $37 \mathrm{P}$ (Forbes) on 4 July 2005

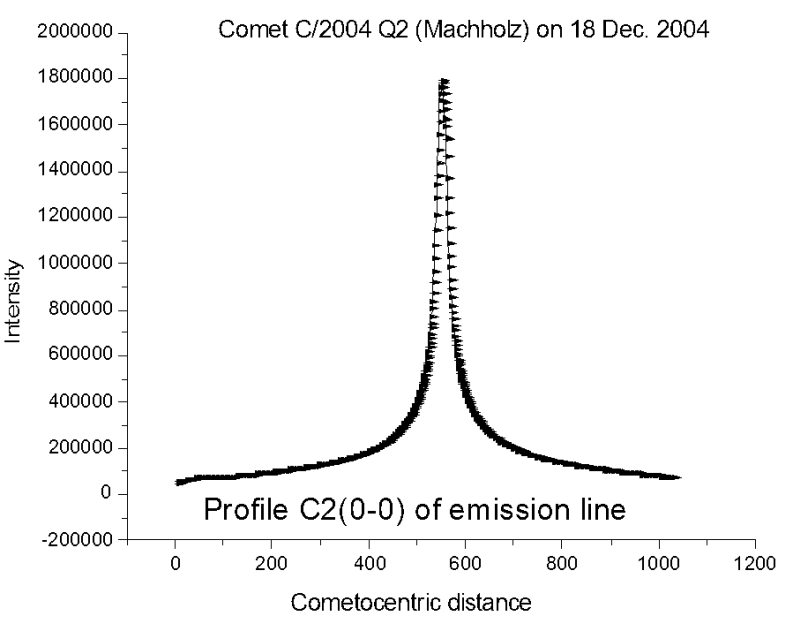

Fig. 7. Profile of brightness in the emission line $\mathrm{C}_{2}(0-0)$ in the spectrum of comet C/2004 Q2 (Machholz) on 18 Dec. 2005 
In this region its intensity reaches 46

For comet 9P/Tempel 1 the level of the luminescent cometary continuum is $30 \%$ of the level of the total cometary continuum with the maximum near wave length $525 \mathrm{~nm}$.

For comet $37 \mathrm{P} /$ Forbes as the preliminary analysis had shown the level of the luminescent cometary continuum is $20 \%$ of the level of the total cometary continuum with the maximum near wave length 450 nm.

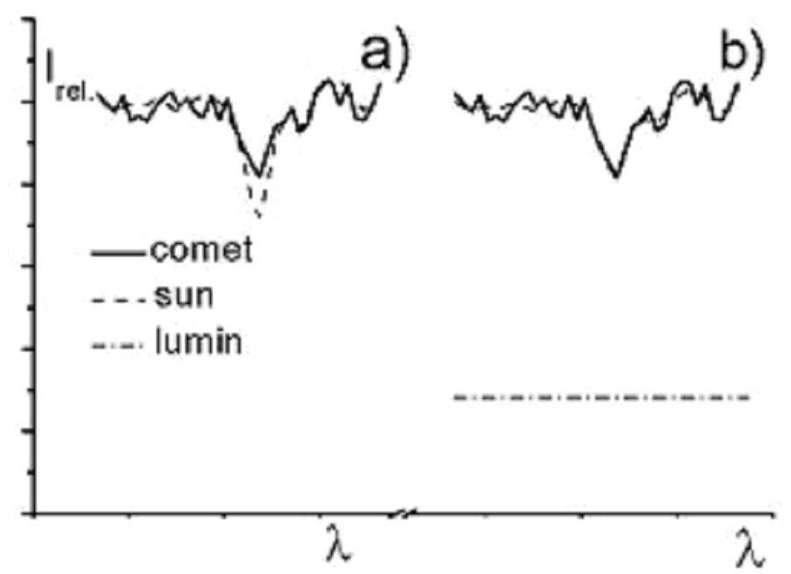

Fig. 8. Detection of a luminescent continuum in a cometary spectrum: a) standard method of determination of a level of the reflected solar spectrum, b) a level of a solar continuum taking into account a luminescent continuum of cometary dust radiation.
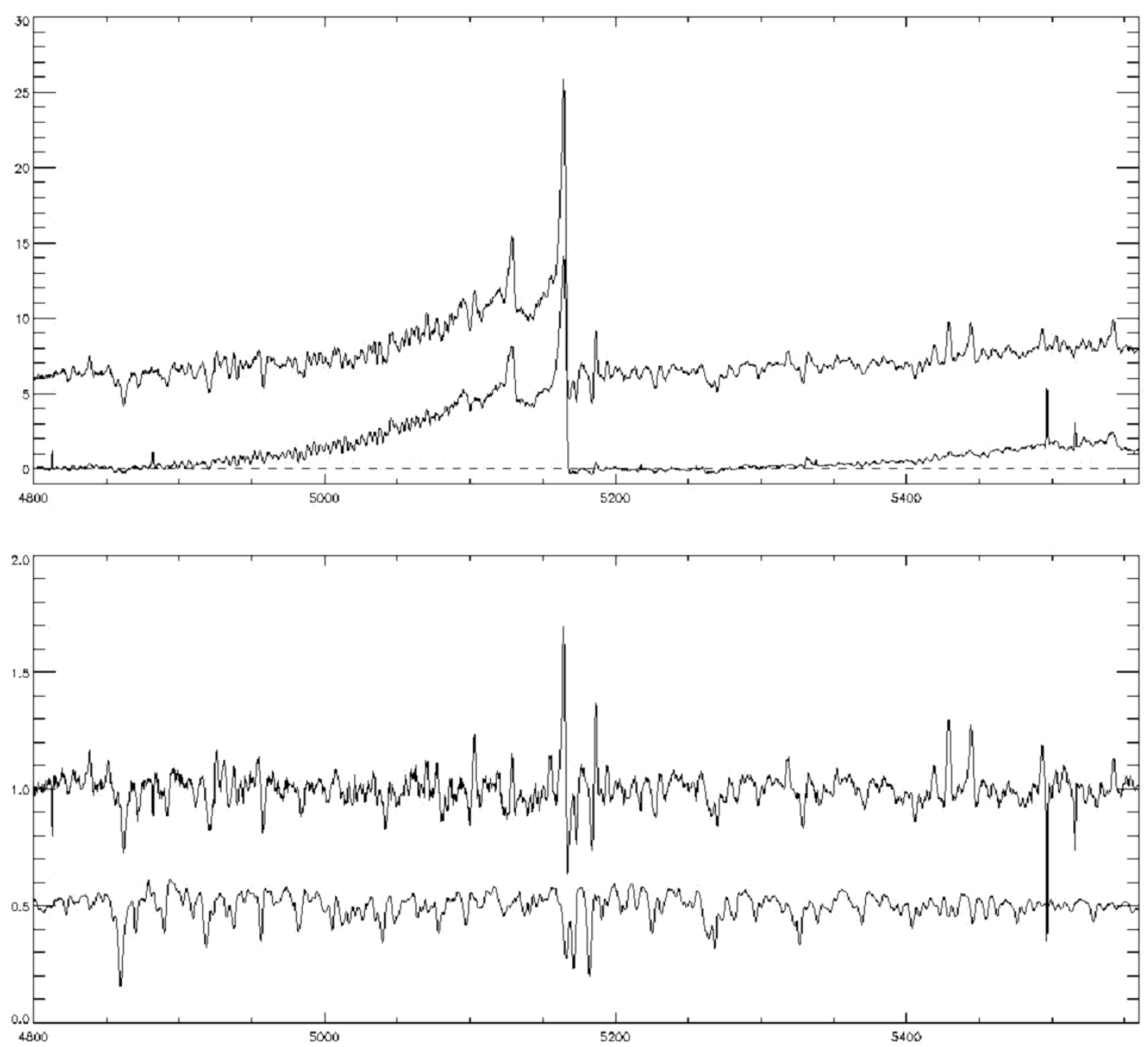

Fig. 9. Detection of the cometary luminescent continuum in the spectrum of comet C/2004 Q2 (Machholz) observed on 15 March 2005 


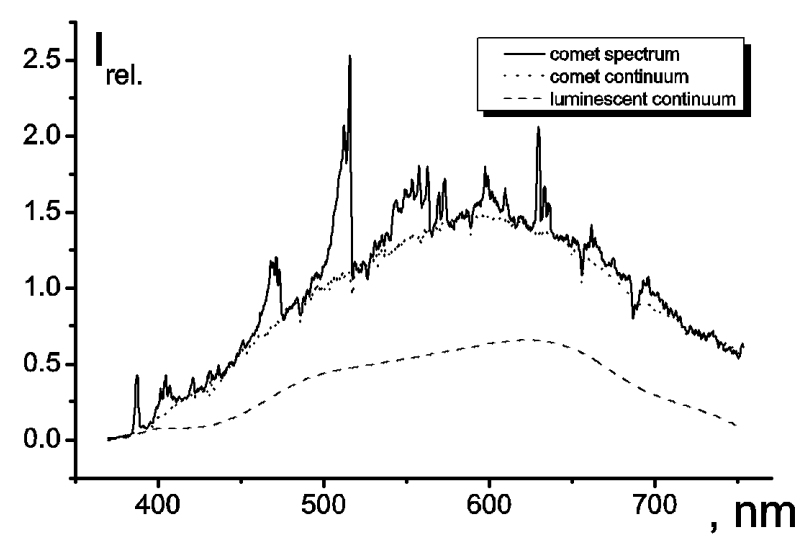

Fig. 10. A spectrum of comet $\mathrm{C} / 2004$ Q2 Machholz with dedicated cometary continuum and a luminescence of cometary dust level of total cometary continuum. Maximum of intensity of the cometary luminescent continuum is close to $630 \mathrm{~nm}[4,5,7]$. In this spectral region the intensity of cometary luminescent continuum equal to $30 \%$ from the total cometary continuum $(42 \%$ from the intensity of the Fraunhopher spectrum).

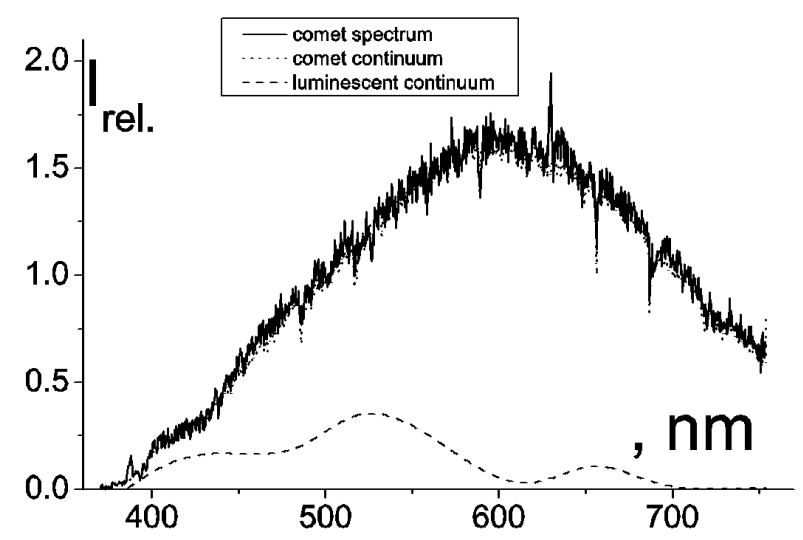

Fig. 11. A spectrum of comet $9 \mathrm{P} /$ Tempel 1 with dedicated cometary continuum and a luminescence of cometary dust level of total cometary continuum

As it was shown by Nazarchuk an Chorny [13] there are following some alternative sources of cometary luminescence continuum in optical region: 1) continuous spectrum of $\mathrm{C}_{2} \mathrm{H}$ radical which arises under photolisis of the $\mathrm{C}_{2} \mathrm{H}_{2}$ molecules; 2) The sputtering of water ice particles at temperature below $100 \mathrm{~K}$ by electrons with the energy between 20 and $300 \mathrm{eV}$; 3) photoluminescence of lonsdeleite crystals which are the white grains of diamond and can be included in composition of graphitev particles; 4) Ordinary scattering by silicates as well as their Roentgen luminescence.

Photoluminescence of the polycyclic aromatic hydrocarbons (PAHs). The analysis shows that the possible contribution 2, 3 and 4 sources is sufficiently slight. Source 1 can contributes to the continuum with the maximum at $510 \mathrm{~nm}$. For details 630,525 and $450 \mathrm{~nm}$, photoluminescence of small PAHs (anthracene $\mathrm{C} 14 \mathrm{H} 10$, pyrene $\mathrm{C} 16 \mathrm{H} 10$, chrysene $\mathrm{C}_{18} \mathrm{H}_{10}$, tetracene $\mathrm{C}_{18} \mathrm{H}_{12}$, and some other PAHs is the most possible.

\section{CONCLUSION}

On the basis of these observations energy distributions in the spectrum for comets 9P/Tempel 1 , C2004 Q1 (Machholz) on March 14-15, 2005 and in the spectrum for comet 37P/Forbes on July 4, 2005 were constructed .

The detailed identification of emission lines in spectra of comet 37P/Forbes was made.

With the help of Shulman's and Haser's models on the basis of analysis of profiles of brightness in selected emission lines along the spectrograph slit some physical parameters of selected molecules of the neutral cometary atmosphere (velocities of the outflow of particles, times of life and length path of parent and daughter molecules for $\mathrm{CN}, \mathrm{C}_{2}$ and $\mathrm{C}_{3}$ were determined. BVRI photometry of comet Tempel 1 and Machholz had shown that comet 9P has color as the Sun, but comet Machholz was bluer very much thaan the Sun.

We suppose that in spectra of comets 9P/Tempel 1, C/2004 Q2 (Machholz) and 37P/Forbes we detected the real luminescent cometary continuum tied with the luminescence of the comet organic species which are in comet dust particles. For comet 9P/Tempel 1 the level of the luminescent cometary continuum is $30 \%$ of the level of the total cometary continuum with the maximum near $525 \mathrm{~nm}$ and for comet C/2004 Q2 (Machholz) the level of the luminescent cometary continuum is $46 \%$ of the level of total cometary continuum with the maximum near $630 \mathrm{~nm}$.

For comet $37 \mathrm{P} /$ Forbes as the preliminary analysis had shown the level of the luminescent cometary continuum is $20 \%$ of the level of the total cometary continuum with the maximum near wave length $450 \mathrm{~nm}$. Comparison of spectra of three comets shows that new comet C/2002 Q2 in Oorts sense has the more high level of luminescent continuum and therefore more number of organic particles. It is main results of the present investigations. 
1. Nazarchuk H.K. // Kometnyj Tsirkulyar. - 1987. - 372. - P.2.

2. Nazarchuk H.K. // Kometnyj Tsirkulyar. - 1987. - 377. - P.2.

3. Churyumov K.I., Kleshchenok V.V., Vlassyuk V.V. Spectral observations of comet P/Schaumasse (1992x) with the 6-meter telescope BTA. // Pisma v Astronomicheskij Journal. - 1994. - 20. - P.76-77.

4. Churyumov K.I., Kleshchenok V.V., Mussaev F.A., et al. Observations of high resolution spectra of comet Hale-Bopp (C/1995 O1) at the SAO of the RAS // Earth, Moon and Planets. - 1999. - 78. - P.105-110.

5. Lukyanyk I.V., Churyumov K.I. Observations of Comet C/2001 A2 (LINEAR) with the Multipupil Fiber Spectrograph // Earth, Moon and Planets. - 2002. - 90. - P.33-41.

6. Churyumov K.I., Lukyanyk I.V., Afanasiev V.L., et al. Exploration of the Comet 19/P Borrelly spectra, obtained with the MPFS and Scorpio of 6-m Telescope on Aug.// Proceedings of Asteroids, Comets, Meteors. - 2002. Technical University Berlin, Germany. - P.657-660.

7. Lukyanyk I.V., Churyumov K.I., Afanasiev V.L., et al. Observation of Spectra and Monochromatic Images of Comet C/2001 A2 (LINEAR) // Proceedings of Asteroids, Comets, Meteors. - 2002. - Technical University Berlin, Germany. - P.717-720.

8. Picazzio E., de Almeida A., Churyumov K.I., Andrievskii S.M., Lukyanyk I.V. The Optical Spectroscopy and Near Infrared Observations of Comet C/2000 WM1 (Linear) in December, 2001 in Chile and Brazil // Earth, Moon and Planets. - 2002. - 90. - P.23-32.

9. Picazzio E., de Almeida A., Churyumov K.I., Andrievskii S.M., Lukyanyk I.V. A high spectral resolution atlas and catalogue of emission lines of the comet C/2000 WM1 (LINEAR // Advances in Space Research. - 2006. - 10. - P.312-322.

10. Chubko L.S., Churyumov K.I., Afanasiev V.L., Lukyanyk I.V. and Kleshchonok V.V. Comparison of the Spectra of the Comets 9P / Tempel 1 and C / 2004 Q2 (Machholz)// Deep Impact as a World Observatory Event: Synergies in Space, Time, and Wavelength. - 2009. - ESO Astrophysics Symposia. - P.197-200.

11. Cochran A. A high spectral resolution Atlas of comet 122P/de Vico. - 2001. (anita@barolo.as.utexas.edu).

12. Shul'man L.M. Distribution of neutral matter density in the cometary atmosphere// Astrometry and Astrophysics. - 1970 . - 11. - P.26-30

13. Chorny G.F., Nazarchuk H.K. Cometary luminophores. - 2001. - Main astronomical observatory of National Academy of Sciences. - reprint. - P.1-16.

Received 18.10.2009 